\title{
The Concept of Peace Education with Dialogic Teaching Approach in History Learning
}

\author{
Ardeti Jeni Abdilla', Sariyatun ${ }^{2}$, Hermanu Joebagio ${ }^{3}$, and Warto ${ }^{4}$ \\ \{ardetijeni@student.uns.ac.id ${ }^{1}$ \} \\ 1,2,3,4 Postgraduate Student of History Education Department, Universitas Sebelas Maret, \\ Surakarta, Indonesia
}

\begin{abstract}
Peace education is a necessity in creating a civil society in today's multicultural world. This article is an attempt to develop the concept and practice of peace education with dialogic teaching approach in history learning. This study used qualitative research method with literature review approach by analyzing articles related to the research corpus, i.e. peace education, dialogic teaching approach, controversial history, and history learning. The results of this study indicate that the dialogic teaching approach is an effective learning approach in teaching controversial historical material. The concept of peace education with dialogic teaching approach in teaching history consist of three learning domains, thus are teaching-learning, instruments, and assumption. The dialogic teaching approach can create a democratic dialogue between students-teacher and studentstudent so that students can build critical thinking skills, as well as responsibility and tolerance. Thus values are important in the peacebuilding process so that students are able to eliminate prejudice and build trust in the social community they are living.
\end{abstract}

Keywords: history learning, peace education, dialogic teaching approach, controversial history

\section{INTRODUCTION}

In the nowadays modern world, conflict occurs no longer between superior power, but between groups that have different cultural entities, especially religions [1]. It has happened in Indonesia's post-reform where the conflict has been characterized by conflicts of ethnicity and religiosity framed in political issues, one of which is the conflict between Muslim and Christian communities. Hundreds to thousands of people had been killed in Ambon 1999-2002, and more than one-third of the total population in Maluku were displaced during the conflict [2]. Much of the conflict was caused by tensions, which were once dampened by authoritarian forces and now emerged. The frequent conflicts in Indonesia indicate that the state of being peace has not yet been formed in Indonesian society. On this basis, it is necessary to build conflict reconciliation by creating an educational design that is able to build a frame of peace.Education has an important role as a "peace dividend" [3] by promoting a form of social cohesion that is often lost during the conflict [4]. It can be done by creating a structured learning design. A 
structured design in learning activities spurs the growth of awareness of peace, tolerance, fairness and non-discriminatory actions.

The concept of peace education emerged as a response to the threat of nuclear weapons during the cold war. the emergence of peace education was officially marked by the establishment of the International Peace Research Association (IPRA) in 1972 which built the paradigm of peace in education. The figures who support the idea of peace education are Johan Galtung and Paulo Freire[5].Today, research on peace education has been specifically developed in certain subjects. It has carried out by several previous researchers, as like Paderangawho conducted research on the using of classroom video conferencing (CVC) as an instructional approach in teaching peace education, and it can increase the awareness level of the students [6]. Furthermore, the results of Arslan, Guncavardi, Polat's research revealed that peace education program (PEP) has a significant to student's intercultural sensitivity[7].Moreover, the research conducted by Claire Bischoff and Mary Elizabeth Mullino Moore concluded that oral history can cultivate the spirit of justice and peace to students [8]. Those studies show that thepeace education needs to be implemented in the context of education today and it requires a certain strategy so that peacebuilding goals can be conveyed.

One of the most important and strategic steps in peace education campaign is establishing the persuasive communication framework. It is a common belief accepted in society and a unity of conscience for the development and creation of the terms of peace [9].Persuasive communication in the learning process can be done by implementing the dialogic teaching approach. Dialogic teaching is not understood as the mere implementation of interactive lessons. Rather, the focus is on improving students' understanding, developing their thinking and raising their participation and engagement with democratic values [10]. One of the school subjects that can build a state of being peace with dialogic teaching strategies is history learning. History learning in this modern world has the role of transmitting ideas about civil society and the life of the state and society through the delivery of past meanings for the sake of the future[11].Demircioglu stated that history learning designed in accordance with the requirements of the era, one of them is having the ability to develop peace, freedom, tolerance, and being open to communication [12].

One of the history learning material that can be used as a discussion material for peace education is controversial history material. But, as a controversial history, it has the complexity faced by teachers so controversial historical material is often deliberately avoided, especially in the communities that have had a history of conflict[13].Along with this direction, this article tries toconceptualizing the dialogic teaching approach in teaching controversial history material. This concept is suggested to cultivate the critical thinking skill, trust and tolerance values as a form of peace education in learning history.

\section{METHOD}

This paper explores peace education in history learning. The purpose of this paper is to bring conceptual clarity to the construct of how peace education integrated with history learning by using the dialogic teachingapproach. The method used to express this notion wasqualitative method with literature review approach. Based John W Cresswell[14], the steps used in explore the data in this study were: 1) identify key terms, the authors identified the literature used as a source of data, thus are articles and books related to peace education, history learning, and dialogic teaching approach; 2) locate literature, the authors sort literature sources based on the novelty of their ideas and their relevance to the direction of the writing of the researcher; 3 ) critically evaluate and select the literature; the authorsanalyzed articles and books related to the 
research corpus, 4) organize the literature; and 5) write a literature review. The result of his paper described how the principles of peace education and how it is applied in historical learning by using the dialogic teachingapproach.

\section{RESULT AND DISCUSSION}

\subsection{Peace Education and History Learning}

Peace education can be defined as an explanation of the reasons why a person must commit to taking part in the peacebuilding. There are four main principles in the teaching of peace education, including: 1) holistic, it means that peace education teaching is a learning process that involves the mind, heart, spirit, as well as action; 2) dialogue, it means peace education is delivered in a class dialogue between students and teachers that enables the establishment of a democratic atmosphere and active participation in learning; 3) critical thinking, means peace education teaching must be designed to encourage students' critical thinking so they can commit to taking a role in building a culture of peace, and 4) build values of peace, it means peace education is expected to build a culture of peace through the values of peace from the spirit of nationality or local wisdom [15].The four principles are the basic principles that must be present in the implementation of peace education in learning. These principles can be elaborated in the development of learning materials that integrate peace education. The development of learning material must be able to reach the cognitive, affective, and psychomotor aspects of students, the implication is that students can have the abilities, skills, and attitudes as can be seen in the following table.

Table 1. The development of peace education material according to UNICEF [16]

\begin{tabular}{|c|c|c|}
\hline Cognitive & Affective & Psychomotor \\
\hline Have self-need awareness & Communication skills & Respect \\
\hline $\begin{array}{l}\text { Have self-awareness } \\
\text { understands conflict and } \\
\text { peace }\end{array}$ & Ability to work together & Tolerance \\
\hline $\begin{array}{l}\text { Have the ability to identify } \\
\text { causes of conflict }\end{array}$ & Ability to think critically & Empathy \\
\hline $\begin{array}{l}\text { Have the ability to } \\
\text { understand the conflict } \\
\text { resolution process }\end{array}$ & $\begin{array}{l}\text { Ability to maintain } \\
\text { relationships with others }\end{array}$ & Responsive to problems \\
\hline $\begin{array}{l}\text { Have analytical skills to } \\
\text { build peace and resolve } \\
\text { conflict }\end{array}$ & Able to deal with emotions & $\begin{array}{l}\text { Accept other people as they } \\
\text { are }\end{array}$ \\
\hline $\begin{array}{l}\text { Understand rights and } \\
\text { responsibilities }\end{array}$ & $\begin{array}{l}\text { The ability to present } \\
\text { alternative solutions }\end{array}$ & Respect differences \\
\hline $\begin{array}{l}\text { Understand the } \\
\text { interdependence between } \\
\text { individuals and society }\end{array}$ & Adaptable & $\begin{array}{l}\text { Respect for social rights and } \\
\text { responsibilities }\end{array}$ \\
\hline \multirow[t]{2}{*}{ Have cultural awareness } & The ability to create peace & $\begin{array}{l}\text { Awareness of gender } \\
\text { differences }\end{array}$ \\
\hline & & Social solidarity \\
\hline
\end{tabular}


The development of peace education material with cognitive, affective, and psychomotor approaches as shown by the table above must be programmed well to facilitate in determining the appropriate material to be taught to students. Paulo Freire stated, peace education aimed to raise learners' critical consciousness must provide the student with an accurate understanding of their social and political contexts while simultaneously focusing attention toward possibilities for action and change [17]. Based on this matter, history learning is an effective subject in developing peace education material. One historical material that can be integrated with the peace education approach is controversial historical material. Controversial historical material can provide students the opportunity to think critically, express opinions democratically, and respond to differences with open-minded and tolerance[18].

The skill that need to be learned by teachers in delivering controversial historical learning is committed impartially, that is the ability of the teacher to discuss controversial issues and explain all the historical points of view to students. In this case, the teacher can use the impartial chairperson strategy, where the teacher briefly explains all controversial historical versions without expressing his personal opinions then students are asked to discuss together. In expressing this attitude the teacher must be guided by three principles, namely neutrality (not tendentious), balance, and reason (based on clear facts) [18].

\subsection{Teaching History with Dialogic Teaching Approach}

The process of implementing controversial history learning needs to consider the learning approach used. One approach that can be used is dialogic teaching. Dialogic teaching is the right approach to teaching controversial history. Because as controversial history learning requires teacher skills that can build open discussions with students, the dialogic teaching approach also requires teachers to have a repertoire of approaches for organizing interaction and engaging in talks to meet the educational goals for the students [19].

Dialogic teaching is a pedagogical approach that capitalizes on the power of talk to further students' thinking, learning, and problem-solving. The focus of dialogic learning approach is on improving students' understanding, developing their thinking and raising their participation and engagement with democratic values[10].According to Alexander[20], there are five principles of dialogic teaching, as follow:

1. Collective: teachers and children address learning tasks together, whether as a group or as a class, rather than in isolation;

2. Reciprocal: teachers and children listen to each other, share ideas and consider alternative viewpoints;

3. Supportive: children articulate their ideas freely, without fear of embarrassment over 'wrong' answers; and they help each other toreach common understandings;

4. Cumulative: teachers and children build on their own and each other's ideas and chain them into coherent lines of thinking andinquiry;

5. Purposeful: teachers plan and facilitate dialogic teaching with particular educational goals in view.

Based on Calcagni\& Lago's research[10], the five principles of the dialogic teaching approach above can be constructed in three domains, namely: 1)Teaching-learning, emphasize how the lessons should happen; 2)Assumptions, belief and worldview that will be developed in learning; and 3)Instrument, containing lesson plans, tasks, and assessments used to support the dialogue learning process. Along with this, the possible implementation of dialogic teaching approach in controversial history learning, for example in the material Gerakan 30 September (The Thirtieth of September Movement), can be observed in the following schema. 


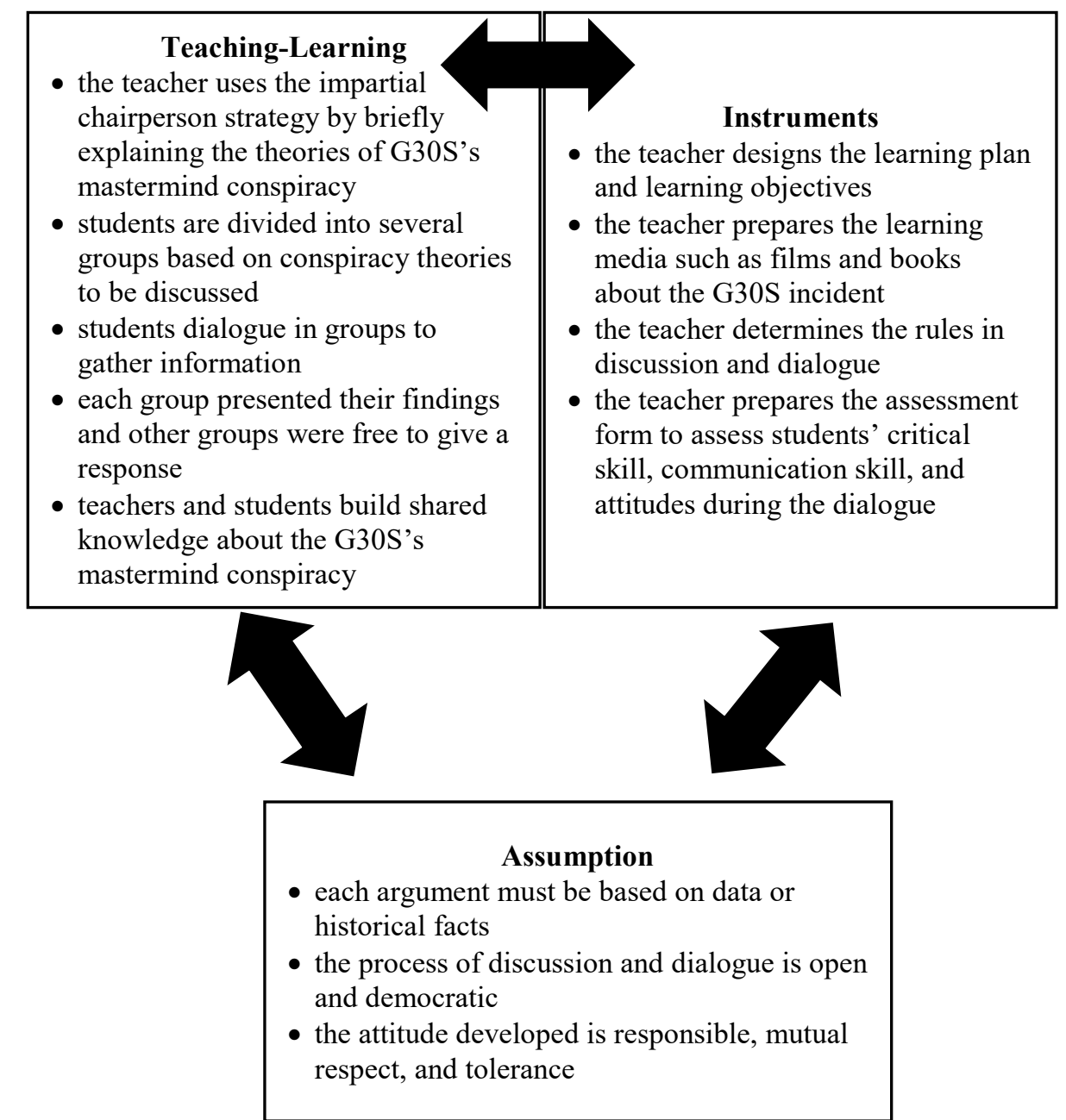

Figure 1. The example schema of dialogical teaching approachin the controversial history of

Gerakan 30 September 1965 (The Thirtieth of September Movement)

Figure 1 shows the praxis of how controversial history is taught by the dialogic teaching approach. The values of peace and skills that can be built from the learning are critical thinking skill, communication skill, democratic, tolerance, mutual trust, and social responsibility. Thus values and skills will create prosocial skill orientation to students, and as mentioned by Gültekin, the prosocial skill is needed to provide the students new perspectives in resolving problems, involves negotiation, and help the student build the culture of consensus and living together in the intercultural community[21]. Moreover, critical thinking skill will possibly create critical emotional awareness and trustful atmosphere in the relation of student-student or studentteacher[22]. These values and skills are important in the peacebuilding process so that students are able to eliminate prejudice and build trust in the social community they are living [23]. 


\section{CONCLUSSION}

Peace education is a relevant idea to overcome the problems of social conflict that often occur today. Historical learning is one of the effective media in internalizing peace education because the conflicts that occur in society today are not infrequently a burden of history that has not been thoroughly discussed. The learning approach that can be used is the dialogic approach. This approachable to elaborate controversial historical facts into learning dialogues that can build students' critical, responsibility and tolerance skills. Thus skills and attitudes formed through democratic dialogue are very important as a provision for students to deal with the conflicts they experience in society. The values of peace and skills that can be built from the learning are critical thinking skill, communication skill, democratic, tolerance, mutual trust, and social responsibility. Thus values and skills are important in the peacebuilding process so that students are able to eliminate prejudice and build trust in the social community they are living

\section{ACKNOWLEDGEMENT}

This presented article is one of the outputs of Postgraduate Thesis Grant 2019, funded by the Ministry of Research, Technology, and Higher Education of Indonesia.

\section{REFERENCES}

[1] S. P. Huntington, The Clash of Civilizations and the Remaking of World Order. New York: Simon \& Schuster, 1996.

[2] ICG, "Indonesia : Trouble again in Ambon," Cris. Gr. Asia Brief., no. 128, 2011.

[3] R. Shah and M. Lopes Cardozo, "Education and social change in post-conflict and postdisaster Aceh, Indonesia," Int. J. Educ. Dev., vol. 38, pp. 2-12, 2014.

[4] S. Tawil and A. Harley, "Education and Identity-based Conflict: Assessing curriculum policy for social and civic reconstruction," Educ. Confl. Soc. Cohes., pp. 3-33, 2004.

[5] R. J. Burns and R. Aspeslagh, Three decades of peace education around the world: An anthology. Routledge, 2014.

[6] L. D. Paderanga, "Classroom Video Conferencing: Its Contribution to Peace Education," Procedia - Soc. Behav. Sci., vol. 123, pp. 113-121, 2014.

[7] Y. Arslan, G. Günçavdı, and S. Polat, "The Impact of Peace Education Programme at University on University Students' Intercultural Sensitivity," Procedia - Soc. Behav. Sci., vol. 174, pp. 2301-2307, 2015.

[8] C. Bischoff and M. E. M. Moore, "Cultivating a spirit for justice and peace: Teaching through oral history," Relig. Educ., vol. 102, no. 2, pp. 151-171, 2007.

[9] B. Gultekin and T. Gultekin, "Communication models and sensitivity approaches for intercultural peace education," in 4th International Conference on New Horizons in Education, 2013, vol. 106, pp. 641-650.

[10] E. Calcagni and L. Lago, "Learning, Culture and Social Interaction The Three Domains for Dialogue : A framework for analysing dialogic approaches to teaching and learning," Learn. Cult. Soc. Interact., vol. 18, no. December 2017, pp. 1-12, 2018.

[11] B. Popovska, "Partnership for Peace Consortium of Defense Academies and Security Studies Institutes The Role of Teaching History for a Nation-Building Process in a PostConflict Society: The Case of Macedonia Author ( s ): Biljana Popovska Published by: Partnership f," vol. 12, no. 1, pp. 51-64, 2012.

[12] E. Ciydem, "The Mission of History Education in Forming Future," vol. 46, pp. 1028- 
$1031,2012$.

[13] K. Kello, "Sensitive and controversial issues in the classroom: Teaching history in a divided society," Teach. Teach. Theory Pract., vol. 22, no. 1, pp. 35-53, 2016.

[14] J. W. Creswell, Educational research : planning, conducting, and evaluating quantitative and qualitative research. MA: Pearson, 2012.

[15] A. Nurcholish, Peace Education dan Pendidikan Perdamaian Gus Dur. Jakarta: Elex Media Komputindo, 2015.

[16] L. Navorro-Castro and J. Nario-Galace, Peace Education: A Pathway to A Culture of Peace. Philippines: Center for Peace Education, 2008.

[17] M. Bajaj, Encyclopedy of Peace Education. Yugoslavia: Information Age Publishing.

[18] T. A. Ahmad, Sejarah Kontroversial di Indonesai: Perspektif Pendidikan. Jakarta: Yayasan Pustaka Obor Indonesia, 2016.

[19] M. Y. Kim and I. A. G. Wilkinson, "What is dialogic teaching? Constructing, deconstructing, and reconstructing a pedagogy of classroom talk," Learn. Cult. Soc. Interact., vol. 21, no. December 2018, pp. 70-86, 2019.

[20] R. . Alexander, Towards dialogic teaching: Rething classroom talk. York, UK: Dialogos, 2017.

[21] B. Gültekin, "Dialog and Mediation Education in Intercultural Communication," Procedia - Soc. Behav. Sci., vol. 55, pp. 1124-1133, 2012.

[22] M. Ojala, "Hope and anticipation in education for a sustainable future \$," Futures, vol. 94, pp. 76-84, 2017.

[23] K. Saddhono and S. Supeni. "The role of dutch colonialism in the political life of Mataram dynasty: A case study of the manuscript of Babad Tanah Jawi." Asian Soc. Sci. vol. 10 no.15 pp. 1-7, 2014 